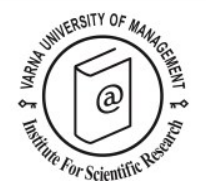

\title{
Subnational tourism competitiveness performance. The Canary Islands vs. the German Länder
}

\author{
Daniel Dorta-Afonso ${ }^{1}$ and Raúl Hernández-Martín ${ }^{2 *}$
}

Received: 17/02/2014 Accepted: 30/10/2014

\footnotetext{
${ }^{1}$ Researcher, University of La Laguna, E-mail: ddortaaf@ull.es

2 Department of Applied Economics, University of La Laguna, Campus de Guajara 38071 La Laguna, Canary Islands, SPAIN, E-mail: rahernan@ull.es, Phone: +34922317014

* Corresponding author
}

\begin{abstract}
The task of measuring the competitiveness of mature destinations, which tend to lose market share in their international markets, is a crucial one. The aim of this paper is to obtain a very detailed view of the competitive position of the Canary Islands in the German market. The special feature of this analysis being that it is performed at a subnational level for both the origin and the destination. More specifically, the analysis combines the federal state (Länder) level and the island level. Starting with the model provided by Ritchie and Crouch for tourism competitiveness, information relating to the habitual place of residence of tourists is sourced and their postcodes are used to perform an analysis of the tourism competitiveness of the Archipelago as a whole, and of each island, in each of the federal states. Differences in tourism competitiveness performance can be used as a powerful information input for destination marketing and management.
\end{abstract}

(C) 2015 Varna University of Management. All rights reserved

Keywords: destination competitiveness, competitiveness index, subnational competitiveness, Canary Islands.

Citation: Dorta-Afonso, D., R. Hernández-Martín (2015) Subnational tourism competitiveness performance. The Canary Islands vs. the German Länder. European Journal of Tourism Research 10 , pp. 51-63

\section{Introduction}

The local economy in the Canary Islands relies heavily on tourism, which has made significant contributions to economic growth in the area for decades. However, nowadays a number of factors are affecting tourism in the islands, thus impacting directly on the tourism competitiveness of the archipelago. The first factor is that the Canary Islands are a mature tourism destination, and since 2000, long before the global economic crisis began in 2007, there has been a stagnation in inbound tourism and expenditure. The second factor is that there has been an increase in the number of emerging destinations worldwide, which has made the global tourism market increasingly competitive. These emerging destinations put pressure on mature destinations, such as the 
Canary Islands, forcing them to rejuvenate and improve quality in order to remain competitive (Krešić and Prebežac, 2011). According to Cracolici and Nijkamp (2009), new, isolated or previously unknown destinations have become the providers of unique and special experiences. Lastly, the third factor has affected tourism is the increase in the global mobility of tourists; what this means in terms of competitiveness is that new competitors are emerging at a global level, and not just at the local level (Croes, 2011).

What is apparent from this is that it is important to take into account two factors when studying tourism competitiveness: changes in tourist behaviour and the emergence of new destinations. Within the literature on tourism, several authors have recognised that in the current context tourists have new and different needs and behaviours, and therefore, new demands are being placed on tourism. The implications of this are that destinations are being forced to adapt in order to meet these new demands (Cracolici and Nijkamp, 2009).

Logically, these changes affect the competitive position of destinations and, as such, measuring competitiveness becomes a crucial task to ensure the short-term and long-term success of a destination. However, measuring competitiveness is far from a simple task; on one hand, the literature contains many different models and indicators for tourism competitiveness, and on the other hand, competitiveness is a relative concept that either i) compares a destination over time, ii) compares several tourism destinations to one another, or iii) compares a destination with its source markets. In this paper, each of these three methodologies shall be combined in order to a) perform a comparative analysis of the tourism competitiveness of the selected destinations in relation to particular source markets, and b) study their evolution and to compare their competitiveness over time. What is unique about the analysis performed, which compares the tourism competitiveness of the main islands of the archipelago - Tenerife, Gran Canaria, Lanzarote, Fuerteventura and La Palma - from the perspective of the different German federal states, is that both the markets and destinations that have been used are not countries, but rather subnational entities. For the purpose of this analysis, up-to-date information was sourced from the Canary Islands Institute of Statistics (ISTAC).

Tourism research and tourism statistics have been traditionally biased towards the national level, which happens, in part, because the international organisation in charge of setting standards on tourism statistics - the United Nations World Tourism Organisation (UNWTO) - has to a certain extent neglected subnational statistics. Nevertheless, tourism activities tend to be very concentrated in certain regions and destinations of each country, and each of these places have their own resources and performance. The relevance of the subnational information and analysis has recently been highlighted by the International Network on Regional Economics, Mobility and Tourism (INRouTe) in a joint methodological publication containing a framework for the development of the measurement and analysis of tourism in a subnational level (UNWTO and INRouTe, 2013). Until now, tourism competitiveness research has been highly concentrated at the national level, due to data availability, but a more magnified look at tourism competitiveness could help to improve the effectiveness of tourism management and planning.

After this introduction, Section 2 of this paper presents a review of existing literature covering different approaches to the study of tourism destination competitiveness, and describes how such measurements are performed. Section 3 details the methodology used to analyse the performance of the Canary Islands in the German federal states. Section 4 provides the results and discussion, and Section 5 contains the conclusions.

\section{Tourism destination competitiveness. Definitions and measurements}

A key concept in the analysis of the relative success of tourism destinations is that of competitiveness (Gooroochurn and Sugiyarto, 2005; Croes, 2011). However, in the literature it is assumed that the competitiveness of tourism destinations is a complex, multidimensional and relative concept (Craigwell, 2007). The complexity of the concept has been deduced 
mainly from the difficulties researchers encounter when trying to reach a consensus on the definition of the concept of competitiveness with regards to tourism destinations, and the difficulties faced when trying to establish the indicators needed to measure it. The reality is that it is a multidimensional concept because the determinants of tourism destination competitiveness are influenced by economic, social, cultural, political, technological and environmental factors (Ritchie and Crouch, 2003).

The relative dimension of the concept refers to its comparative nature; it is possible to a) analyse destinations over time (WEF, 2013); b) compare two or more destinations in terms of their competitiveness (Hassan, 2000; Dwyer and Kim, 2003; Hong, 2008; Gomezelj and Mihalic, 2008; Dwyer et al., 2012; Falzon, 2012; Huang and Peng, 2012; Zhang et al., 2011; Kozak and Rimmington, 1999); and c) compare the position of destinations in relation to their source markets (Dwyer et al., 2000; Li et al., 2013; Kim and Agrusa, 2005, Azzoni and de Menezes, 2009; Benedetti et al., 2011). However, despite being presented as separate approaches above, these three approaches can be combined, and indeed, they are often used together by researchers.

The aim of this paper is to compare the competitive position of several destinations in different source markets. The methodology being used enables us to achieve this as it is possible to perform a comparative analysis of a single destination over time and also a comparative analysis of destinations against one another within each of the source markets.

Competitiveness can be analysed in terms of its determinants (WEF, 2013; Dwyer et al., 2000; Dragićević et al., 2012; Enright and
Newton, 2005), its performance or results (Li et al., 2013; Cracolici and Nijkamp, 2009, Botti et al., 2009; Kozak and Rimmington, 1999; Cracolici et al., 2008; Sanchez Rivero, 2012) or both (Claver-Cortés et al., 2007). Most studies focus on the analysis of the competitiveness of tourism destinations in terms of its determinants. The analysis of countries in these studies tends to rely on aspects such as infrastructure, service quality, or price competitiveness to determine which country is most likely to attract tourists. Some authors suggest that a destination is competitive only when it is able to turn their advantageous conditions into satisfactory results in the form of tourism revenue (Li et al., 2013). These authors conclude that merely having an advantage, such as lower price offers (determinant), will not necessarily see it transformed into higher tourism receipts (result), which is the key factor. In this paper, performance is used when analysing the tourism competitiveness of the five main tourism islands of the Archipelago. Therefore, in Table 1 below, approaches E, F, $\mathrm{G}$ and $\mathrm{H}$ have been applied.

Over recent decades different authors have defined tourism destination competitiveness using several different variables. For example, Poon (1993:24) offers four principles that tourism destinations should follow if they want to be competitive, "put the environment first, make tourism a lead sector, strengthen the distribution channels in the market-place and build a dynamic private sector". However, these guidelines have proven too broad and tourism destinations have found it difficult to take them into significant consideration (Dwyer and Kim, 2003). Since then, other researchers have highlighted the economic dimensions of tourism destination competitiveness, i.e. profits, growth in comparison to their competitors, tourist arrivals and tourist expenditure (Hong, 2008;

Table 1. Approaches to analyse tourism competitiveness

\begin{tabular}{lcccc} 
& Through time & $\begin{array}{c}\text { Among destinations } \\
\text { (same origin) }\end{array}$ & $\begin{array}{c}\text { Among origins } \\
\text { (same destination) }\end{array}$ & $\begin{array}{c}\text { Among origins and } \\
\text { destinations }\end{array}$ \\
\hline Determinants & A & B & C & D \\
Performance / results & E & F & G & H \\
\hline
\end{tabular}


Ritchie and Crouch, 2003; Dwyer and Kim, 2003; Hassan, 2000; d'Hauteserre, 2000; Botti et al., 2009; Claver-Cortés et al., 2007). Other studies have highlighted the importance of experience and tourist satisfaction as the determinants of tourism competitiveness (Dwyer and Kim, 2003; Enright and Newton, 2004; Ritchie and Crouch, 2003; Alegre and Garau, 2009). Other authors in the literature have also highlighted the environmental variable. These authors view the environment and the preservation of resources as a crucial aspect of tourism that must be taken into consideration if a destination is to be competitive (Poon, 1993; Hassan, 2000; Ritchie and Crouch, 2003; Hu and Wall, 2005; Jacob, Florido and Aguiló, 2010; Hernández and León, 2013). Despite these different perspectives, what does seem to be generally accepted is that the ultimate goal of competitiveness is to improve economic welfare and the quality of life of a destination's residents (Romão, Guerreiro, and Rodrigues, 2013; Buhalis, 2000; Crouch and Ritchie, 1999; Ritchie and Crouch, 2003; Dwyer and Kim, 2003; Hong, 2009).

According to most of the aforementioned authors, including Mazanec, Wöber and Zins (2007), Croes (2011), Romão, Guerreiro and Rodrigues (2013), Andrades-Caldito, SánchezRivero and Pulido-Fernández (2013), the most accepted definition of tourism destination competitiveness in the academic literature is that given by Ritchie and Crouch (2003), which emphasizes the aspects which have just been highlighted: the growth of the economic dimension (number of tourists and expenditure), tourist satisfaction (memorable experiences), the environmental variable, and the welfare of residents:

"What makes a tourism destination truly competitive is its ability to increase tourism expenditure, to increasingly attract visitors while providing them with satisfying, memorable experiences, and to do so in a profitable way, while enhancing the wellbeing of destination residents and preserving the natural capital of the destination for future generations." (Ritchie and Crouch, 2003:2).
In this paper, this definition is used as a framework for research as it was agreed that it includes all the main dimensions for defining the concept of competitiveness that appear in the literature. The research done by Ritchie and Crouch has been used as a framework for other works focusing in the analysis of tourism destination competitiveness (Cracolici, Nijkamp and Rietveld, 2008; Enright and Newton, 2004, 2005; Andrades-Caldito, Sánchez-Rivero, and Pulido-Fernández, 2013; Crouch, 2011).

In trying to resolve the lack of consensus on the concept of competitiveness, it was also apparent that there is a lack of consensus on how competitiveness is measured and that significant controversy surrounds the debate on which factors actually influence it. Prices are considered to be one of the most important factors in explaining tourism competitiveness (Craigwell, 2007; Bolaky, 2011; Dwyer, Forsyth and Rao, 2000; Durbarry and Sinclair, 2003; Marrero and Santana, 2008; Gooroochurn and Sugiyarto, 2005; Falzon, 2012; Azzoni and de Menezes, 2009). Dwyer, Forsyth and Rao (2000) highlight the importance of price competitiveness as a determinant of destination performance based on the influence pricing has on tourist flows. These authors developed an indicator that encompasses transport prices, both to and from the destination, and the services at the destination for the purposes of conducting a study to analyse price competitiveness; their aim was to study the price competitiveness of Australia in relation to other 18 competitors, which also took into account its source markets. Ideally, the measurement of tourism price competitiveness should include the prices of the main products consumed by tourists (Gooroochurn and Sugiyarto, 2005), but several authors have recognised the difficulty in obtaining statistical data relating to the prices of tourism goods and services (Dwyer and Forsyth 2011; Espinet et al., 2012).

The variables that determine competitiveness are numerous and not just limited to pricing. Destination competitiveness is influenced by many factors and all these factors must be analysed using indicators (Dwyer and Kim, 2003). Some authors claim that tourism competitiveness is measured by tourist arrivals 
at a destination and formulate their competitiveness measurement models using indicators that influence tourist arrivals. Craigwell (2007) claims that tourist arrivals depend on technological advantages, advantages in industrial organization and in prices, and proposes a set of indicators to measure the competitiveness of destinations based on these factors. This model is later extended by Bolaky (2011) who, in addition to the aforementioned factors, makes arrivals dependent on the following: infrastructurerelated advantages, the environment, social factors such as health, and also exogenous factors such as a destination's history and culture. In other studies, instead of using arrivals as the dependent variable researchers have used overnight stays in tourism accommodation (Romão, Guerreiro and Rodrigues, 2013). Another indicator that is often used to measure the success of a tourism destination is tourist expenditure as it is closely related to the stimulation of economic activity (Hong, 2008).

However, according to Croes (2011), some destinations do not want to constantly increase the number of arrivals as they wish to avoid exceeding their carrying capacity. In the academic literature, the environmental factor is seen as a determinant of the competitiveness of tourism destinations (Hassan, 2000; Jacob, Florido and Aguilo, 2010; Bolaky, 2011; ClaverCortés et al., 2007). Furthermore, the appeal of certain attributes of the destination, measured using tourism surveys, has also been used to build tourism competitiveness indicators (Cracolici and Nijkamp, 2009; Alegre and Garau, 2009).

Other studies measuring the competitiveness of tourism destinations have chosen to use a set of indicators that compare the different attributes of competing destinations (Dwyer et al, 2012; Uysal, Chen and Williams, 2000; Huang and Peng, 2012; Zhang et al., 2011; Kim and Agrusa, 2005; Dragićević et al., 2012; Armenski et al., 2012). In keeping with this line of investigation, other methodologies have been identified that involve the use of stakeholder surveys (Dwyer et al., 2012; Dragićević et al., 2012; Armenski et al., 2012), tourism surveys (Uysal et al., 2000; Kim and
Agrusa, 2005), and also statistical information obtained from the official websites of international and governmental institutions (Huang and Peng, 2012; Zhang et al., 2011). It should be emphasized that some studies include the product (sun and beach, honeymoons, sports, etc.) in order to establish which destinations are defined as competitor destinations and which attributes are to be valued, and not the whole range of products offered in a given destination (Kim and Agrusa, 2005; Dragićević et al., 2012).

Limitations in aggregating the different variables that are involved in the study of tourism destination competitiveness have been overcome thanks to the development of synthetic indices. The Travel and Tourism Competitiveness Report (World Economic Forum, 2013) provides an analysis of the competitiveness of 140 countries using 79 indicators grouped into 14 pillars. These indicators measure different elements such as price competitiveness, aspects of infrastructure and destination resources.

\section{Methodology}

Our research includes two key elements: firstly, the concept of tourism competitiveness and the indicators that are applied to the German Länder, and secondly, the database from which the necessary information has been obtained. The indicators used have been developed from the concept of competitive destinations provided by Ritchie and Crouch (2003), while the necessary data for the study has been obtained primarily from the Tourism Expenditure Survey of the Canary Islands Institute of Statistics.

\section{Tourism competitiveness indicators}

As already mentioned, the definition of tourism competitiveness provided by Ritchie and Crouch (2003) has been used in this paper to empirically analyse the competitiveness of each of the Canary Islands in a number of source markets in Germany. As this analysis involves comparing similar origin markets with several destinations, it is not possible to include changes in the welfare of the residents in each destination (island) as an explaining variable. In other words, according to this analysis an increase in the welfare of the residents of any 
Table 2. Selection of indicators

\begin{tabular}{ll}
\hline Ritchie and Crouch definition (2003) & Indicator used \\
\hline “...increase tourism expenditure" & 1. Tourist Expenditure \\
“...attract visitors" & 2. Number of Tourists \\
“...satisfying, memorable experiences" & 3. General Satisfaction \\
“...preserving the natural capital" & 4. Satisfaction with Environmental Factors \\
“...well-being of destination residents" & Not applicable to German Länder
\end{tabular}

of the Canary Islands which results from tourists showing the same expenditure and satisfaction patterns is therefore the same, regardless of the Länder from which these tourists originate. As such, in this paper four indicators are being proposed for the purpose of measuring tourism competitiveness in relation to the elements of Ritchie and Crouch's definition in Table 2.

In following Ritchie and Crouch's definition (2003) it is possible to observe that a destination is competitive when it is able to increase both visitor arrivals and expenditure. Therefore, the average daily expenditure of tourists visiting the Canary Islands has been used for indicator one, whilst the gross propensity to travel (see Fletcher et al., 2013) of the residents from each state weighted by the number of tourism beds offered in each island has been used for indicator two. With regards to the general satisfaction of tourists, indicator three is based on the answers provided in the tourism surveys that are completed by tourists following their stay; information pertaining to the overall stay satisfaction has been used. Similarly, for environmental factors, indicator number four, the information used is that which is obtained from the answers given by tourists concerning different aspects of the natural capital of the islands. In this paper we will present results for the year 2012 and a comparison against the year 2011.

\section{Index of tourist expenditure - Ite}

The proposed indicator is the average daily expenditure of tourists visiting the Canary Islands, which is a normalised indicator allowing for comparisons among origins and destinations. In the following indexes $t$ is the period, $\mathrm{d}$ is the destination (the island), and $\mathrm{o}$ refers to the origin (the Länder).

Ite ${ }_{t, d}^{o}=\frac{\text { Aggregate tourist expenditur } \mathrm{e}_{t, d}^{o}}{\text { Tourist overnights }{ }_{t, d}^{o}}$

The average daily expenditure is the total amount of money spent by tourists divided by overnight stays. It must be noted that the total amount of money spent by tourists includes all the components of the travel (flight, accommodation, excursions, souvenirs, etc.). The main problem of using this value is that the cost of transportation will not have a direct effect on the economy of the destination; however, due to the availability of data, we have decided to use this indicator as the estimation of transportation costs would not be accurate enough in order to exclude it from the analysis. Additionally, although the definition of Ritchie and Crouch (2003) uses increase of expenditure as the key variable, in this paper we compare several destinations and therefore we use expenditure levels as the relevant variable for comparison.

\section{Index of the number of tourists - Int}

The economic impact of tourism is mainly influenced by the number of tourists and their expenditure. Therefore, an inbound tourism index has been built. The proposed indicator is the gross propensity of travel to each of the Canary Islands of the resident population in each Länder normalized using the number of available bed-places in the island. Those regions with a larger population tend to have a larger amount of outbound tourists. In addition, tourism developed islands are those with the capacity to attract more tourists, so the number of tourist beds offered is used as a control 
variable. This is a normalised indicator of expenditure.

$$
\text { Int } t_{t, d}^{o}=\frac{\text { Gross propensityto travel }}{\text { Numberof Beds } s_{t}^{d}}
$$

Index of satisfaction - Is

The destination must be perceived as a global product capable of generating satisfactory experiences. The indicator proposed in this paper is the ratio of tourists who value their stay as good or very good.

$$
I S_{t, d}^{o}=\frac{\text { Tourist evaluation } " g o o d " \text { or } " v e r y ~ g o o d "{ }_{t, d}^{o}}{\text { All tourists }{ }_{t, d}^{o}}
$$

\section{Index of environmental quality - $E F$}

The environment is key to ensuring tourism competitiveness. However, the literature recognizes the difficulty of measuring the environmental variables (Crouch, 2011). From the point of view of tourism competitiveness, perception on environmental aspects may be as important as the existing environmental quality. The choice of indicators can vary depending on the analyst's goal (Dwyer and Forsyth, 2011) and objective as well as subjective indicators can be used in order to measure an attribute of destination tourism competitiveness (Ritchie and Crouch, 2003). We consider that a subjective measure is more coherent with the purpose of assessing tourism destination competitiveness from a results perspective.

The proposed indicator is an average of the valuation made by tourists on a scale 1-10 (after their stay) of the main factors related to the quality of the environment: quality of bathing areas, landscapes, quality of the environment, and general cleanliness. competitiveness of a given destination in relation to different outbound markets. To do so, the technical report made by the Joint Research Centre of the European Commission (Nardo et al., 2005) has been taken into consideration for the purpose of building composite indicators. This process can be accomplished with the help of minimum and maximum values, like Goorochurn and Sugiyarto (2005). Furthermore, in this paper the normalization criterion is stable over time in order to make inter-temporal comparisons. For this purpose, maximum and minimum observed values in 2011 are used. Then, following a similar methodology to the one used by the World Economic Forum (2013) in developing the Travel and Tourism Competitiveness Index, the un-weighted arithmetic mean of the standardized indicators is used to build the composite indicator of tourism destination competitiveness. The estimation of weights for each variable involves further subjectivity from decision makers and further debate on the method chosen as each method can lead to different results (Botti and Peypoch, 2013).

\section{Database}

Once these indicators have been defined, information concerning each German Länder is then obtained. The segmentation of the German market has been conducted using the postcodes of tourists. Since the second quarter of 2010, the Canary Islands Institute of Statistics has been collecting the postcodes of tourists who come to the islands as part of the Survey of Tourist Expenditure, however, these data were not published until June 2013.

The tourist expenditure survey conducted by the Canary Islands Institute of Statistics is classified among those that obtain statistical data through sample enumeration. Its main purpose is to identify the expenditure patterns

$$
E F_{t, d}^{o}=\frac{\text { Landscapes }_{, d}^{o}+\text { Bathing Areas }_{t, d}^{o}+\text { Cleanliness }_{t, d}^{o}+\text { Qualityof Environment }_{t, d}^{o}}{4}
$$

Standardization and construction of a composite index

Once the tourism competitiveness indicators are obtained, they are standardized in order to build a synthetic index of the tourism of tourists visiting the Canary Islands, their socio-demographic profile and the characteristics of their trips. Respondents are always aged 16 years old or over and the survey is conducted in the five international airports of the Canary Islands following their 
stay in the islands. As a result, all kinds of tourism segments are included in the sample (holiday makers, those visiting friends and relatives, business travellers, etc.).

The survey sample size is 36,000 questionnaires per year. In 2012 the number of questionnaires completed by German tourists was 7,704 or in other words, $23 \%$ of the total sample size. Regarding the German Länder, the sample can be broken down as follows:

Table 3. Size of the sample

\begin{tabular}{lrr}
\hline & $\mathbf{2 0 1 1}$ & $\mathbf{2 0 1 2}$ \\
\cline { 2 - 3 } Baden-Württemberg & 828 & 979 \\
Bayern & 939 & 996 \\
Berlin & 366 & 423 \\
Brandenburg & 168 & 186 \\
Hamburg & 319 & 320 \\
Hessen & 496 & 556 \\
Niedersachsen & 773 & 956 \\
Nordrhein-Westfalen & 1.916 & 1.796 \\
Rheinland-Pfalz & 335 & 323 \\
Sachsen & 228 & 286 \\
Sachsen-Anhalt & 123 & 123 \\
Schleswig-Holstein & 316 & 364 \\
Other Länder & 372 & 396 \\
Germany & 7.179 & 7.704 \\
\hline Source: ISTAC & &
\end{tabular}

\section{Results}

In this section a brief description of the markets is presented based on tourist behaviour, which takes into account the Länder that they come from. The main results of the research are also presented and explained in order to provide an understanding of and insight into the competitive position of the Canary Islands in the German outbound markets.

\section{Description of outbound markets}

This section begins with a presentation of some basic facts about the different German Länder followed by differences in the behaviour of tourists who visit the islands. German states are heterogeneous in nature: on one hand, certain states could be perceived of as cities due to their extension, i.e. Berlin, Bremen and Hamburg. A large section of the total population live in these Länder and the population density is high; however in other states, such as Brandenburg, the population density is much lower because it extends over a large territory.

In the case of Germany, which has more than 80 million inhabitants, it would be far too generalizing to speak about them as a whole so in order to gain a better understanding of tourist profile and behaviour, a detailed geographical segmentation of the markets must be performed.

In performing this geographical segmentation, it was found that if we focus our attention on the length of stay of German tourists in the Canary Islands during 2012, those from Berlin spent more nights at the destination, whereas in contrast tourists from Baden-Württemberg stayed the least number of nights (11.7 vs. 9.7 days). It was also found that the use of allinclusive accommodation amongst tourists who came from Sachsen-Anhalt was higher than for those who live in Hamburg (52.7\% vs. $28.6 \%$ ). In addition, the results show that more than $20 \%$ of tourists from Berlin booked both their flight and accommodation using the Internet, while this figure stands at $10 \%$ for tourists from other Länder, such as Brandenburg or Sachsen-Anhalt. Consequently, tourists from these Länder were found to use travel agencies most frequently.

\section{Competitiveness indicators by Länder}

In this section, the competitiveness indicators defined in the previous section are applied to the market segments (Länder). However, it is important to highlight that due to the size of the sample the states of Bremen, MecklenburgVorpommern, Saarland and Thüringen have been grouped together under 'Other Länder'.

Table 4 below shows the results of the four proposed indicators for measuring the competitiveness of the Canary Islands by market (Länder) and also by synthetic indicator. In looking at the different indicators it is possible to easily appreciate that the competitive position of the Canary Islands differs depending on the German federal state in question: for the indicator expenditure, tourists coming from those Länder located in 
the south - Hessen, Bayern, Rheinland-Pfalz, etc. - demonstrate a higher daily average expenditure than those arriving from others; for the indicator 'number of tourists', the competitive position of the archipelago is better among the federal states located in the northwest and also Berlin, while the federal states of the south show intermediate results. The worst performance of this indicator among the different Länder can be found in those located in the northeast of the country (with the exception of Berlin); for the indicator 'general satisfaction', the opposite trend is seen. Performance is better in the Länder located in the northeast compared to those in the northwest, while satisfaction figures are intermediate in the south; and for the indicator 'environmental factors', the value is higher in the northeast, in the Länder of Berlin, Brandenburg and Sachsen.

Table 5 below shows the competitive position of each of the islands in relation to each Länder. The synthetic index shows that the island of Lanzarote demonstrates the best performance in the German market, whereas Tenerife shows the worst performance $(0.55$ vs. 0.39). This table can be read in two ways. It

Table 4. Standardized competitiveness indicators by Länder 2012 for the Canary Islands

\begin{tabular}{lccccc} 
& $\begin{array}{c}\text { Tourist } \\
\text { Expenditure }\end{array}$ & $\begin{array}{c}\text { Number of } \\
\text { Tourists }\end{array}$ & $\begin{array}{c}\text { Satisfaction } \\
\text { Bnvironmental } \\
\text { Factors }\end{array}$ & $\begin{array}{c}\text { Composite } \\
\text { Index }\end{array}$ \\
\hline Baden-Württemberg & 0.72 & 0.21 & 0.57 & 0.31 & 0.45 \\
Bayern & 0.80 & 0.19 & 0.59 & 0.21 & 0.45 \\
Berlin & 0.73 & 0.29 & 0.63 & 0.38 & 0.51 \\
Brandenburg & 0.72 & 0.16 & 0.78 & 0.40 & 0.51 \\
Hamburg & 0.66 & 0.44 & 0.29 & 0.06 & 0.36 \\
Hessen & 0.91 & 0.23 & 0.59 & 0.20 & 0.48 \\
Niedersachsen & 0.68 & 0.30 & 0.39 & 0.22 & 0.39 \\
Nordrhein-Westfalen & 0.63 & 0.24 & 0.54 & 0.25 & 0.41 \\
Rheinland-Pfalz & 0.79 & 0.19 & 0.43 & 0.12 & 0.38 \\
Sachsen & 0.52 & 0.18 & 0.76 & 0.34 & 0.45 \\
Sachsen-Anhalt & 0.55 & 0.13 & 0.63 & 0.24 & 0.39 \\
Schleswig-Holstein & 0.66 & 0.32 & 0.60 & 0.05 & 0.41 \\
Other Länder & 0.77 & 0.18 & 0.61 & 0.21 & 0.44 \\
Total Germany & 0.71 & 0.23 & 0.55 & 0.24 & 0.43 \\
\hline
\end{tabular}

Source: own elaboration with data provided by ISTAC

Table 5. Synthetic index by island and federal state. 2012

\begin{tabular}{lcccccc} 
& Lanzarote & Fuerteventura & $\begin{array}{c}\text { Gran } \\
\text { Canaria }\end{array}$ & Tenerife & La Palma & $\begin{array}{c}\text { Canary } \\
\text { Islands }\end{array}$ \\
\hline Baden-Württemberg & 0.54 & 0.40 & 0.53 & 0.44 & 0.44 & 0.45 \\
Bayern & 0.49 & 0.43 & 0.43 & 0.48 & 0.46 & 0.45 \\
Berlin & 0.58 & 0.51 & 0.57 & 0.44 & 0.33 & 0.51 \\
Brandenburg & 0.66 & 0.42 & 0.59 & 0.48 & 0.47 & 0.51 \\
Hamburg & 0.44 & 0.48 & 0.38 & 0.24 & 0.46 & 0.36 \\
Hessen & 0.70 & 0.47 & 0.44 & 0.42 & 0.46 & 0.48 \\
Niedersachsen & 0.60 & 0.40 & 0.35 & 0.33 & 0.48 & 0.39 \\
Nordrhein-Westfalen & 0.52 & 0.38 & 0.45 & 0.39 & 0.40 & 0.41 \\
Rheinland-Pfalz & 0.57 & 0.36 & 0.34 & 0.37 & 0.50 & 0.38 \\
Sachsen & 0.62 & 0.40 & 0.45 & 0.40 & 0.56 & 0.45 \\
Sachsen-Anhalt & 0.65 & 0.34 & 0.47 & 0.23 & 0.55 & 0.39 \\
Schleswig-Holstein & 0.54 & 0.37 & 0.52 & 0.28 & 0.46 & 0.41 \\
Other Länder & 0.63 & 0.39 & 0.36 & 0.45 & 0.50 & 0.44 \\
Total Germany & 0.55 & 0.41 & 0.43 & 0.39 & 0.44 & 0.43 \\
\hline Source: OWn & 0.53
\end{tabular}

Source: own elaboration with data provided by ISTAC. Statisches Bundesamt for population figures. 
can either be used to obtain information from an island perspective, and thus identify the Länder in which the island is performing its best; from this point of view, Lanzarote is more competitive in Hessen than in the rest of the Länder, while Fuerteventura, Gran Canaria and Tenerife perform better in Brandenburg and La Palma in Sachsen. Or, the table can be used to obtain information from the Länder perspective and establish which island performs better in each state - for example, Fuerteventura is the most competitive island in Hamburg.

Figure 1 below shows the competitive position of the Canary Islands, as a whole, in relation to each Länder enabling us to providing a ranking.

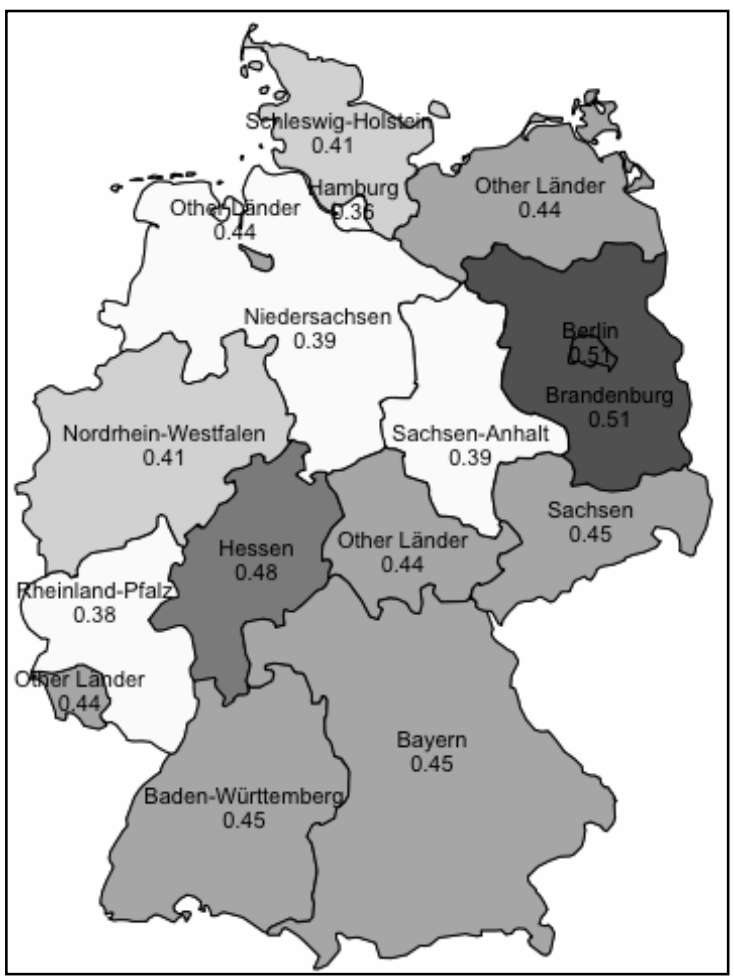

Figure 1. Tourism competitiveness synthetic index in the Canary Islands 2012

The competitive position of the archipelago is better in Brandenburg and Berlin, which occupy first and second positions in the ranking. In general, the tourism competitiveness of the Canary Islands in 2012 is higher in the Länder of the East and the South. However, in the federal states located next to The Netherlands and Belgium as well as in Sachsen-Anhalt, the synthetic indicator of tourism competitiveness shows lower values.

In a dynamic analysis, it should be noted that Berlin was amongst one of the last in 2011, but its performance in the four indicators is much better in 2012 and consequently its competitive performance has increased by $27 \%$, placing it in second position. The opposite has occurred with regards to Hamburg. The competitive position of Hamburg for the Canary Islands was at its best in 2011. However due to a $34 \%$ decrease in 2012 the Canary Islands perform their worst in this particular Länder for this year.

\section{Conclusions}

As there is still no consensus on the definition of tourism destination competitiveness, nor in the methodology that should be used to measure it, this paper has sought to provide a methodology and composite index that will allow researchers to analyse competitiveness. In this paper, the methodology proposed is designed to measure competitiveness using indicators that are consistent with the definition by Ritchie and Crouch (2003) as this definition is the one that most authors consider to be the most thorough and accurate. Our methodology has been designed to allow researchers to compare the competitive position of several destinations in relation to several markets over time.

In this paper, the authors have provided an analysis of the competitive position of each of the Canary Islands in relation to each of the German Länder as subnational entities have been used for both markets and destinations instead of using countries, thus expanding on previous studies. What was found according to the indicators used based on the definition by Ritchie and Crouch (2003) is that the competitive position of each destination is quite different in each of the markets. According to the expenditure results, the archipelago as a whole is more competitive in Hessen than in the rest of the Länder. However, according to the number of tourists indicator, performance is better in Hamburg, and for both the satisfaction and environmental factors indicators, performance is better in Brandenburg. The differences found in the performance of each islands for each indicator and each origin 
market can be considered as a powerful tool for future tourism marketing strategies. Until now, given the lack of data, such a detailed analysis related to competitiveness performance at a subnational level was not possible.

Given the fact that performance is seen to differ depending on which of the indicators is being referenced, a synthetic index was developed in order to analyse the overall competitive position of individual destinations. Once the composite index was built, the overall competitive position of each destination was analysed. According to this new composite index, the archipelago as a whole is more competitive in Hessen than the rest of the Länder. If we look at each island, Lanzarote is the most competitive island in the German market, although there are noticeable differences in its performance in each Länder. As stated before, this methodology allows researchers to analyse competitiveness from a destination perspective as well as from an origin market perspective, thus allowing researchers to identify the competitiveness of a destination against others in a given origin market, and also to identify where a destination performs best overall.

This research has been devoted to developing a way to obtain an overview of competitiveness results of several destinations (islands) in several origins (regions), giving rise to many new questions related to the explanation of the performance observed. One of the main limitations of the proposed methodology concerns the weighting of each of the indicators when building the composite index. The other limitation is the quality of the indicators used to measure each of the variables. Nevertheless, these limitations are common in this type of research. Therefore, the results must be considered as an approach to reality and not conclusive. In this paper the four indicators have been given the same weight, in keeping with the methodology used by the World Economic Forum in the TTCI (2013). However, some stakeholders may use other indicators or may take the stance that some indicators should have more weight in competitiveness than others. Further research should consider giving different weight to each indicator when building the composite index, whilst bearing in mind that this may introduce new problems in terms of interpreting and comparing results. The explanation of the patterns of behaviour observed in the paper remains a research problem to be addressed in the future.

\section{References}

Andrades-Caldito, L., Sánchez-Rivero, M. \& Pulido-Fernández, J.I. (2013). Differentiating competitiveness through tourism image assessment: An application to Andalusia (Spain). Journal of Travel Research, 52(1), 68-81.

Alegre, J. \& Garau, J. (2009). Tourist satisfaction indices. A critical approach. Investigaciones regionales, 14, 5-26.

Armenski, T., Gomezelj, D.O., Djurdjev, B., Ćurcić, N. \& Dragin, A. (2012). Tourism destination competitiveness between two flags. Ekonomska istraživanja, 25(2), 485502.

Azzoni, C.R., \& de Menezes, T.A. (2009). Cost competitiveness of international destinations. Annals of Tourism Research, 36(4), 715-739.

Benedetti, J., Çakmak, E. \& Dinnie, K (2011). The competitive identity of Brazil as a Dutch holiday destination. Place Branding and Public Diplomacy, 7(2), 107-115.

Bolaky, B. (2011). Tourism competitiveness in the Caribbean. CEPAL Review, 104, 55-76.

Botti, L., Peypoch, N., Robinot, E. \& Solonadrasana, B. (2009). Tourism destination competitiveness: the French regions case. European Journal of Tourism Research, 2(1), 5-24.

Botti, L. and Peypoch, N. (2013). Multi-criteria ELECTRE method and destination competitiveness. Tourism Management Perspectives, 6, 108-113.

Buhalis, D (2000). Marketing the competitive destination of the future. Tourism Management, 21(1), 97-116.

Claver-Cortés, E., Molina-Azorín, J.F. \& Pereira-Moliner, J. (2007) Competitiveness in mass tourism. Annals of Tourism Research, 34(3), 727-745.

Cracolici, M.F. \& Nijkamp P. (2009). The attractiveness and competitiveness of tourism destinations: A study of Southern Italian regions. Tourism Management, 30(3), 336-344. 
Cracolici, M.F., Nijkamp, P. \& Rietveld, P. (2008). Assessment of tourism competitiveness by analysing destination efficiency. Tourism Economics, 14(2), 325342.

Craigwell, R. (2007). Tourism competitiveness in small island developing states. United Nations University, Research Paper No. 2007/19.

Croes, R. (2011). Measuring and explaining competitiveness in the context of small island destinations. Journal of Travel Research, 50(4), 431-442.

Crouch, G.I. (2011). Destination competetiveness: An analysis of determinant attributes. Journal of Travel Research, 50(1), 27-45.

Crouch, G.I. \& Ritchie, J.R.B. (1999). Tourism, competitiveness, and societal prosperity. Journal of Business Research, 44(3), 137 152.

d'Hauteserre, A.M. (2000). Lessons in managed destination competitiveness: the case of Foxwoods Casino Resort. Tourism Management, 21(1), 23-32.

Dragićević, V., Jovicłć, D., Blešić, I., Stankov, U. \& Bošković, D. (2012). Business tourism destination competitiveness: a case of Vojvodina province (Serbia). Ekonomska istraživanja, 25(2), 311-332.

Durbarry, R. \& Sinclair, M.T. (2003). Market shares analysis: the case of French tourism demand. Annals of Tourism Research, 30(4), 927-941.

Dwyer, L., Cvelbar, L.K., Edwards, D. \& Mihalic, T. (2012). Fashioning a destination tourism future: The case of Slovenia. Tourism Management, 33(2), 305-316.

Dwyer, L., Forsyth, P. \& Rao, P. (2000). The price competitiveness of travel and tourism: a comparison of 19 destinations. Tourism Management, 21(1), 9-22.

Dwyer, L., \& Kim, C. (2003). Destination competitiveness: Determinants and indicators. Current Issues in Tourism, 6(5), 369-414.

Dwyer, L. \& Forsyth, P. (2011). Methods of estimating destination price competetiveness: a case of horses for courses? Current Issues in Tourism, 14(8), 751-777.

Enright, M.J. \& Newton, J. (2004). Tourism destination competitiveness: a quantitative approach. Tourism Management, 25(6), 777-788.

Enright, M.J. \& Newton, J. (2005). Determinants of Tourism Destination Competitiveness in Asia Pacific: Comprehensiveness and Universality. Journal of Travel Research, 43(4), 339-350.

Espinet, J.M., Fluvià M., Rigall-I-Torrent, R. \& Saló, A. (2012). Hotel characteristics and seasonality in prices: an analysis using Spanish tour operators' brochures. Tourism Economics, 18(4), 749-767.

Falzon J. (2012). The price competitive position of Mediterranean countries in tourism: Evidence from the Thomson brochure. Tourism Management, 33(5), 1080-1092.

Fletcher, J., Fyall, A., Gilbert, D. \& Wanhill, S. (2013). Tourism: Principles and Practice. 5th Edition. Pearson, Harlow.

Gomezelj, D. \& Mihalic, T. (2008). Destination competitiveness: Applying different models, the case of Slovenia. Tourism Management, 29(2), 294-307.

Gooroochurn, N. \& Sugiyarto, G. (2005). Competitiveness indicators in the travel and tourism industry. Tourism Economics, 11(1), 25-43.

Hassan, S.S. (2000). Determinants of market competitiveness in an environmentally sustainable tourism industry. Journal of Travel Research, 38(3), 239-245.

Hernández, J.M. \& León, C.J. (2013). Welfare and environmental degradation in a tourism-based economy. Tourism Economics, 19(1), 5-35.

Hong, W.C. (2008). Competitiveness in the tourism sector. A comprehensive approach from economic and management points. Heidelberg: Physica-Verlag.

Hong, W.C. (2009). Global competitiveness measurement for the tourism sector. Current Issues in Tourism, 12(2), 105-132.

$\mathrm{Hu}$, W. \& Wall, G. (2005). Environmental management, environmental image and the competitive tourist attraction. Journal of Sustainable Tourism, 13(6), 617-635.

Huang, J.H. \& Peng, K.H. (2012). Fuzzy Rasch model in TOPSIS: A new approach for generating fuzzy numbers to assess the competitiveness of the tourism industries in Asian countries. Tourism Management, 33(2), 456-465. 
International Network on Regional Economics, Mobility and Tourism and World Tourism Organization (2012). A Closer Look at Tourism: Sub-national Measurement and Analysis - Towards a Set of UNWTO Guidelines. UNWTO, Madrid.

Jacob, M., Florido C. \& Aguilo, E. (2010). Environmental innovation as a competitiveness factor in the Balearic Islands. Tourism Economics, 16(3), 755764.

Kozak, M. \& Rimmington, M. (1999). Measuring tourism destination competitiveness: conceptual considerations and empirical findings. International Journal of Hospitality Management, 18(3), 273-283.

Kresic, D. \& Prebezac, D. (2011). Index of destination attractiveness as a tool for destination attractiveness assessment. Tourism, 59(4), 497-517.

Li, G., Song, H., Cao, Z. \& Wu, D.C. (2013). How competitive is Hong Kong against its competitors? An econometric study. Tourism Management, 36, 247-256.

Mazanec, J.A., Wöber, K. \& Zins, A.H. (2007). Tourism destination competitiveness: From definition to explanation? Journal of Travel Research, 46(1), 86-95.

Nardo, M., Saisana, M., Saltelli, A. \& Tarantola, S. (2005). Tools for composite indicators building. Technical report. European Comission.
Poon, A. (1993).Tourism, technology, and competitive strategy. Wallingford: $\mathrm{CAB}$ International.

Ritchie, J.R.B. \& Crouch, G.I. (2003).The competitive destination: $A$ sustainable tourism perspective. Wallingford: CAB.

Romão, J., Guerreiro, J. \& Rodrigues, P.M.M. (2013). Territorial Differentiation, Competitiveness and Sustainability of Tourism, In Matias, A. et al. (eds.) (2013). Quantitative methods in tourism economics. pp. 271-285. Heidelberg: Physica-Verlag.

Kim, S.S., \& Agrusa, J. (2005). The positioning of overseas honeymoon destinations. Annals of Tourism Research, 32(4), 887904.

Uysal, M., Chen, J.S. \& Williams, D.R. (2000). Increasing state market share through a regional positioning. Tourism Management, 21(1), 89-96.

World Economic Forum (2007, 2009, 2011, 2013). The Travel \& Tourism Competitiveness Report. Geneva: WEF.

Zhang, H., Gu, C.-L., Gu, L.-W. \& Zhang, Y. (2011). The evaluation of tourism destination competitiveness by TOPSIS \& information entropy - A case in the Yangtze River Delta of China. Tourism Management, 32(2), 443-451. 